\title{
PENGARUH BERBAGAI KONSENTRASI BIOINSEKTISIDA (Beauveria bassiana) TERHADAP KEMATIANIMAGO Aedes aegypti TAHUN 2017
}

\author{
Nanda Prihatiningsih ${ }^{*}$, Mela Firdaust ${ }^{* *}$ \\ Jurusan Kesehatan Lingkungan, Politeknik Kesehatan Kemenkes Semarang, \\ Jl.Raya Baturaden KM 12 Purwokerto, Indonesia
}

\begin{abstract}
Abstrak
Pengendalian insektisida hayati sejauh ini masih belum banyak dikembangkan untuk memutus siklus hidup nyamuk khususnya diaplikasikan terhadap nyamuk dewasa (imago). Bioinsektisida (Beauveria bassiana) merupakan bioinsektisida dengan bahan aktif jamur Beauveria bassiana yang dapat menginfeksi melalui kulit Imago Aedes aegypti yang ramah lingkungan dan tidak dapat menimbulkan resistensi. Tujuan penelitian ini adalah untuk mengetahui berbagai pengaruh bioinsektisida (Beauveria bassiana) terhadap kematian imago Aedes aegypti. Jenis penelitian ini termasuk penelitian eksperimen dengan desain post test only with control group desain. Hasil penelitian pengamatan selama 48 jam pada konsentrasi $10 \%$ adalah 1,3\% (1), konsentrasi $20 \%$ adalah 5,3\% (4) dan konsentrasi $30 \%$ adalah 18,6\% (14). Standar Pengujian Efikasi Pestisida konsentrasi yang efektif adalah $>90 \%$ sehingga dapat disimpulkan pada hasil penelitian bioinsektisida (Beauveria basssiana) belum efektif untuk membunuh imago Aedes aegypti karena belum mampu membunuh imago Aedes aegypti $>$ 90\%.
\end{abstract}

Kata kunci: Imago Aedes aegypti, bioinsektisida (Beauveria bassiana) ; kesehatan lingkungan

\begin{abstract}
The effect of various concentrations of bioinsectiside (Beauveria bassiana) to the death of Aedes aegypti imago in 2017. There is only a few research about controlling biological insecticide to discontinue the life cycleof mosquito especially the Imago, which is a form of the adult mosquito. Beauveria bassiana canbe used as a bioinsecticide that consist of Beauveria bassiana fungus, which acts as a parasite on the leather of the Aedes aegypti Imago, which can be used as an eco-friendly bioinsecticide with no causing resistant to the Aedes aegypti. The objective of this study is to find out the effects of Beauveria bassiana bioinsecticide to the death of Aedes aegypti Imago. The methodology used in this research is an experimental research with the post-test design only with control group design. The results of this study by observing 48 hours are; at $10 \%$ concentration is 1,3\% (1), at $20 \%$ concentration is $5,3 \%$ (4) and at 30 concentration is $18,6 \%$ (14). The standard efficacy testing effective concentration is $>90 \%$. The writer can conclude that the result of this study is not effective to eradicate the Aedes aegypti $>90 \%$.
\end{abstract}

Keywords: Aedes aegypti imago, bioinsektisida (Beauveria bassiana), environmenthal health

\begin{abstract}
Pendahuluan
Menurut Permenkes RI No. 374/MENKES/PER/III/2010 penyakit yang ditularkan melalui vektor masih menjadi penyakit endemis yang dapat menimbulkan wabah atau kejadian luar biasa serta dapat menimbulkan gangguan kesehatan masyarakat, sehingga perlu dilakukan upaya pengendalian atas penyebaran vektor. Oleh sebab itu diperlukan adanya pengendalian vektor. Pengendalian vektor adalah semua kegiatan atau tindakan yang ditujukan untuk menurunkan populasi vektor serendah
\end{abstract}

mungkin sehingga keberadaannya tidak lagi berisiko untuk terjadinya penularan penyakit tular vektor di suatu wilayah atau menghindari kontak masyarakat dengan vektor sehingga penularan penyakit tular vektor dapat dicegah. Salah satu penyakit yang dapat menimbulkan wabah atau kejadian luar biasa (KLB) yaitu penyakit Demam Berdarah Dengue (DBD). Jumlah kasus Demam Berdarah Dengue (DBD) di Kabupaten Banyumas pada lima tahun terakhir mengalami fluktuatif. Hasil pendataan dari Dinas Kesehatan Kabupaten Banyumas jumlah kasus DBD 
adalah sebagai berikut : 200 orang pada tahun 2012, 543 orang pada tahun 2013, 206 orang pada tahun 2014, 264 orang pada tahun 2015, dan 1281 orang pada tahun 2016. Purwokerto barat merupakan daerah dengan kasus tertinggi di Kabupaten Banyumas dengan jumlah 111 kasus DBD. Bila dibandingkan dengan tahun sebelumnya, mengalami peningkatan yang sangat signifikan.

Secara teknis upaya pengendalian vektor perlu diterapkan pendekatan pengendalian vektor terpadu (PVT) yang salah satu prinsipnya adalah penggunaan insektisida merupakan pilihan terakhir dan dilakukan secara rasional serta bijaksana. Karena itu aplikasi insektisida dalam pengendalian vektor perlu mempertimbangkan beberapa aspek yaitu efektif terhadap serangga sasaran, teknologi aplikasinya, keamanaan bagi kesehatan masyarakat, petugas, dan lingkungan. Penggunaan insektisida untuk pengendalian vektor dapat berperan ganda yaitu mampu memutuskan rantai penularan penyakit. Namun bila penggunaannya kurang bijak akan memberikan dampak negatif antara lain menimbulkan kematian organisme bukan sasaran, menimbulkan masalah lingkungan dan menimbulkan resistensi bagi vektor (Direktur Jenderal PP dan PL, 2012).

Bioinsektisida Beuveria bassiana yang bersifat sporadis (jamur memakan hama) manfaat untuk mengendalikan hama serangga dan ulat secara aman dan ramah lingkungan. Bahan aktif Bioinsektisida adalah jamur Beuveria bassiana. Menurut Arsyiogi Hendra Samuel Sibrani, 2015 cara jamur Beauveria bassiana menginfeksi serangga adalah Beauveria bassiana mengadakan penetrasi ke dalam tubuh serangga melalui kulit luar di antara ruas-ruas. Mekanisme penetrasi dimulai dengan pertumbuhan konidia pada kutikula serangga dan mebentuk apresoria yang akhirnya membentuk hifa. Selanjutnya hifa cendawan tersebut mengeluarkan enzim kitinase, lipase, dan proteinase yang mampu menguraikan komponen menyusun kutikula serangga. Di samping itu cendawan ini juga memproduksi racun beauvericin yang dapat menyebabkan kerusakan pada jaringan maupun organ haemocoel serangga seperti saluran pencernaan, otot, sistem syaraf, dan system pernafasan. Akibat dari keseluruhan system di atas maka akan berakhir dengan kematian serangga

Hasil penelitian Maharani Herawan Ossa Putri, 2015 pendedahan 48 jam dengan pengenceran $10^{-1}$ sampai $10^{-6}$ jumlah imago Aedes aegpti yang terinfeksi sebesar 100\% (30) ekor, 90\% (27) ekor, 80\% (24) ekor, $63 \%$ (19) ekor, 50\% (15) ekor, dan 33\% (10) ekor.

Tujuan penelitian adalah untuk mengetahui pengaruh berbagai konsentrasi bioinsektisida (Beauveria

\footnotetext{
${ }^{*}$ E-mail: nandap022@gmail.com

${ }^{* *}$ E-mail: melafirdaust@yahoo.co.id
}

bassiana) terhadap kematian imago Aedes aegypti

\section{Bahan dan Metode}

Penelitian dilakukan dengan metode eksperrimental yaitu quasy experiment dengan desain Post Test Only with Control Group Desain. Penelitian menggunakan imago Aedes aegypti dengan menggunakan larutan bioinsektisida (Beauveria bassiana) yang terdiri dari berbagai konsentrasi yaitu kontrol, konsentrasi 10\%, konsentrasi 20\%, konsentrasi 30\%. Imago Aedes aegypti yang digunakan sebanyak 25 untuk setiap perlakuan. Penelitian dilakukan dengan 3 kali replikasi, parameter yang diamati adalah jumlah kematian imago Aedes aegypti yang telah diberi perlakuan selama 48 jam.

Cara kerja

Penelitian dilakukan di Laboratorium Entomologi Balai Litbang P2B2 Banjarnegara. Dalam penelian ini Imago Aedes aegypti berasal dari ruang rearing yang ada di Balai Litbang P2B2 Banjarnegara. Imago Aedes aegypti yang telah ada kemudian dimasukan kedalam kurungan nyamuk sebanyak 25 ekor dengan ukuran $30 \mathrm{~cm} \times 30 \mathrm{~cm}$ x $30 \mathrm{~cm}$ untuk setiap perlakuan. Pembuatan larutan dilakukan dengan menimbang bioinsektisida (Beauveria bassiana). Timbang 1 gram bioinsektisida (Beauveria bassiana) kemudian dilarutkan dalam $10 \mathrm{ml}$ air untuk konsentrasi 10\%, 2 gram bioinsektisida (Beauveria bassiana) kemudian dilarutkan dalam $10 \mathrm{ml}$ air untuk konsentrasi 20\%, 3 gram bioinsektisida (Beauveria bassiana) kemudian dilarutkan dalam $10 \mathrm{ml}$ air untuk konsentrasi 30\% dan untuk kontrol tanpa diberi perlakuan. Ambil sebanyak 5 $\mathrm{ml}$ dari masing-masing konsentrasi dan masukan ke dalam botol spray. Setelah itu, semprotkan dengan cara mengelilingi kurungan nyamuk sampai habis. Kemudian jumlah kematian imago Aedes aegypti diamati dan dicatat setelah diinfeksi 48 jam.

Data yang kuantitatif yang telah diolah, kemudian data dianalisis secara statistik menggunakan uji Analisis of Variance (ANOVA) untuk mengetahui apakah ada perbedaan yang bermakna antar variasi berbagai konsentrasi bioinsektisida (Beauveria bassiana) pada kematian imago Aedes aegypti, apabila data tidak berdistribusi normal atau tidak homogen maka data diuji dengan menggunakan uji Kruskal Wallis. Apabila hasil uji Krusskal Wallis signifikan, maka dilanjutkan dengan uji U Man Whitney . Dan untuk memperkirakan konsentrasi yang tepat untuk membunuh imago Aedes aegypti 25 (100\%) maka digunakan uji Regresi Linear.

\section{Hasil dan Pembahasan}

\section{Pengukuran Kelembaban}

Kelembaban udara diukur menggunakan thermohygrometer, pengukuran dilakukan pada saat melakukan penelitian replikasi ke-1, ke-2 dan ke-3 karena pada saat penelitian dilakukan replikasi dengan waktu yang berbeda. Pengukuran kelembaban dilakukan pada awal 
dan di akhir perlakuan. Berdasarkan tabel 1. dapat diketahui kelembaban udara rata - rata pada ruang penelitian replikasi ke-1 67,35\% ; replikasi ke-2 69,2\% dan replikasi ke-3 67,8\%. Hasil tersebut sangat cocok untuk perkembangan nyamuk.

Tabel 1. Hasil Pengukuran Kelembaban Udara Ruang Penelitian Balai Litbang P2B2 Banjarnegara

\begin{tabular}{|c|c|c|c|c|}
\hline No & $\begin{array}{c}\text { Replika } \\
\text { si }\end{array}$ & $\begin{array}{c}\text { Kelemba } \\
\text { ban } \\
\text { Awal } \\
\text { (\%) }\end{array}$ & $\begin{array}{c}\text { Kelemba } \\
\text { ban } \\
\text { Akhir } \\
\text { (\%) }\end{array}$ & $\begin{array}{c}\text { Kelemba } \\
\text { ban } \\
\text { Rata-rata } \\
\text { (\%) }\end{array}$ \\
\hline 1 & $\begin{array}{c}\text { Ke-1 } \\
2-4 \\
\text { Mei } \\
2017\end{array}$ & 66,7 & 68 & 67,35 \\
\hline 2 & $\begin{array}{c}\text { Ke-2 } \\
4-6 \\
\text { Mei } \\
2017\end{array}$ & 67,2 & 71,2 & 69,2 \\
\hline 3 & $\begin{array}{c}\text { Ke-3 } \\
8-10 \\
\text { Mei } \\
2017\end{array}$ & 68 & 67,6 & 67,8 \\
\hline
\end{tabular}

Kelembaban udara adalah banyaknya kandungan uap air dalam udara yang biasanya dinyatakan dalam prosen (\%). Jika dalam udara ada kekurangan air yang besar, maka udara ini mempunyai daya penguapan yang besar. Sistem pernafasan pada nyamuk adalah menggunakan spiracle. Adanya spiracle yang terbuka tanpa ada mekanisme pengaturannya, pada waktu kelembaban rendah akan menyebabkan penguapan air dari dalam tubuh nyamuk yang dapat mengakibatkan keringnya cairan tubuh nyamuk. Salah satu musuh nyamuk adalah penguapan. Pada kelembaban kurang dari 60\% umur nyamuk akan menjadi pendek sehingga tidak cukup untuk siklus pertumbuhan parasit di dalam tubuh nyamuk. (Ditjend PPM \& PL, 2004)

Kebutuhan kelembaban yang tinggi mempengaruhi nyamuk untuk mencari tempat yang lembab dan basah sebagai tempat hinggap atau istirahat. Pada kelembaban kurang dari 60\% umur nyamuk menjadi pendek. (Depkes RI Ditjen PP \& PL, 2007, h.9)

Kelembaban juga merupakan salah satu kondisi lingkungan yang dapat mempengaruhi perkembangan nyamuk Aedes aegypty. Spiracle (lubang pada dinding tubuh nyamuk) yang terbuka lebar pada saat kelembaban rendah dan terjadi penguapan air dalam tubuh nyamuk yang menimbulkan keringnya cairan tubuh nyamuk (Memory Fitri Sitorus, 3013). Menurut Cecep dani Sucipto, 2011, h.54 dalam (Farida larasati 2013) pada kelembaban < 60\% umur nyamuk akan pendek, sehingga tidak cukup untuk siklus perkembangbiakan virDen dalam tubuh nyamuk. Kondisi ruang penelitian masih memenuhi syarat untuk kehidupan nyamuk sehingga kematian nyamuk bukan karena faktor kelembaban udara.

\section{Pengukuran Suhu}

Suhu udara diukur menggunakan thermohygrometer, pengukuran dilakukan pada saat melakukan penelitian replikasi ke-1, ke-2 dan ke-3 karena pada saat penelitian dilakukan replikasi dengan waktu yang berbeda. Pengukuran suhu udara dilakukan pada awal dan di akhir perlakuan. Berdasarkan tabel 2. dapat diketahui suhu udara rata - rata pada ruang penelitian adalah $28^{0} \mathrm{C}$. Suhu yang diperoleh di ruang penelitian stabil, hal tersebut dikarenakan ruang penelitian yang digunakan dilengkapi dengan pendingin udara (air conditioner).

Tabel 2. Hasil Pengukuran Suhu Udara Ruang Penelitian Balai Litbang P2B2 Banjarnegara

\begin{tabular}{|c|c|c|c|c|}
\hline No & $\begin{array}{l}\text { Replika } \\
\text { si }\end{array}$ & $\begin{array}{l}\text { Suhu } \\
\text { Awal } \\
\left({ }^{0} \mathrm{C}\right)\end{array}$ & $\begin{array}{c}\text { Suhu } \\
\text { Akhir } \\
\left({ }^{0} \mathrm{C}\right)\end{array}$ & $\begin{array}{c}\text { Suhu } \\
\text { Rata-rata } \\
\left({ }^{0} \mathrm{C}\right)\end{array}$ \\
\hline 1 & $\begin{array}{c}\text { Ke-1 } \\
\text { 2-4 Mei } \\
2017 \\
\text { Ke-? }\end{array}$ & 28 & 28 & 28 \\
\hline 2 & $\begin{array}{c}\text { 4-6 Mei } \\
2017\end{array}$ & 28 & 28 & 28 \\
\hline 3 & $\begin{array}{c}\text { Ke-3 } \\
8-10 \\
\text { Mei } \\
2017\end{array}$ & 28 & 28 & 28 \\
\hline
\end{tabular}

Trijayanti, 2015), suhu udara yang optimal untuk perkembangbiakan nyamuk berkisar antara $20^{\circ} \mathrm{C}-30^{\circ} \mathrm{C}$. Nyamuk adalah binatang berdarah dingin, oleh sebab itu proses metabolisme dan siklus kehidupannya tergantung pada suhu lingkungan. Nyamuk tidak dapat mengatur suhu tubuhnya sendiri terhadap perubahan-perubahan di luar tubuhnya

Nyamuk dapat bertahan hidup dalam suhu rendah, akan tetapi proses metabolismenya menurun atau bahkan terhenti bila suhu turun sampai dibawah suhu kritis dan pada suhu yang sangat tinggi akan mengalami perubahan proses fisiologisnya. Pertumbuhan nyamuk akan terhenti sama sekali bila suhu kurang dari $10^{\circ} \mathrm{C}$ atau lebih dari $40^{\circ} \mathrm{C}$. Toleransi terhadap suhu tergantung pada spesies nyamuknya, tetapi pada umumnya suatu spesies tidak akan tahan lama bila suhu lingkungan meninggi $5^{0} \mathrm{C}-6^{0} \mathrm{C}$ diatas batas dimana spesies secara normal dapat beradaptasi (Ditjend PPM \& PL, 2004)

Menurut Wahyuni S dalam (Andy Kurniawan, 2012) Suhu yang tinggi akan meningkatkan aktivitas nyamuk dan perkembangannya bisa menjadi lebih cepat, tetapi apabila suhu di atas 35 akan membatasi populasi nyamuk. Suhu optimum berkisar antara $20^{\circ} \mathrm{C}-30^{\circ} \mathrm{C}$. Makin tinggi suhu makin pendek masa inkubasi ekstrinsik (sporogoni) dan sebaliknya semakin rendah 
suhu semakin panjang masa inkubasi masa ekstrinsiknya.

\section{Kematian Imago Aedes aegypti}

Kematian nyamuk Aedes aegypti setelah kontak langsung dengan Bioinsektisida (Beauvaria bassiana) dengan berbagai Konsentrasi selama 48 jam.

Tabel 3. Hasil Pengamatan Imago Aedes aegypti selama penelitian di Laboratorium Entomologi Balai Litbang P2B2 Banjarnegara

\begin{tabular}{|c|c|c|c|c|c|}
\hline No & $\begin{array}{c}\text { Kons } \\
\text { entra } \\
\text { si }\end{array}$ & $\begin{array}{c}\text { Rep } \\
\text { lika } \\
\text { si }\end{array}$ & $\begin{array}{c}\text { Jumlah } \\
\text { Nya- } \\
\text { muk }\end{array}$ & $\begin{array}{c}\text { Jumlah } \\
\text { Nyamu } \\
\text { k Mati } \\
\text { 48 Jam }\end{array}$ & $\begin{array}{c}\text { Presentase } \\
\text { Kematian } \\
\text { 48 Jam } \\
(\%)\end{array}$ \\
\hline \multirow{3}{*}{1} & \multirow{3}{*}{$\begin{array}{c}\text { Kon } \\
\text { trol }\end{array}$} & 1 & 25 & 0 & \multirow{3}{*}{$0 \%$} \\
\hline & & 2 & 25 & 0 & \\
\hline & & 3 & 25 & 0 & \\
\hline \multirow{3}{*}{2} & & 1 & 25 & 1 & \multirow{3}{*}{$1,3 \%$} \\
\hline & $10 \%$ & 2 & 25 & 0 & \\
\hline & & 3 & 25 & 0 & \\
\hline \multirow{3}{*}{3} & & 1 & 25 & 2 & \multirow{3}{*}{$5,3 \%$} \\
\hline & $20 \%$ & 2 & 25 & 1 & \\
\hline & & 3 & 25 & 1 & \\
\hline \multirow{3}{*}{4} & & 1 & 25 & 8 & \multirow{3}{*}{$18,6 \%$} \\
\hline & $30 \%$ & 2 & 25 & 2 & \\
\hline & & 3 & 25 & 4 & \\
\hline
\end{tabular}

Standar Pengujian Efikasi Pestisida konsentrasi yang efektif adalah $>90 \%$ sehingga dapat disimpulkan pada hasil penelitian pada tabel 4.3 bioinsektisida (Beauveria basssiana) belum efektif untuk membunuh imago Aedes aegypti karena belum mampu membunuh imago Aedes aegypti sampai $>90 \%$.

Bioinsektisida (Beauveria basssiana) belum efektif untuk membunuh imago Aedes agypti dimungkinkan karena kondisi lingkungan pada saat penyimpanan bioinsektisida (Beauveria basssiana) tidak sesuai dengan suhu pertumbuhan jamur Beauveria bassiana tidak bisa tetap hidup sehingga bioinsektisida (Beauveria basssiana) yang digunakan tidak optimal. Menurut (Goral dan Lappa dalam Vina Nathalia, 2011) suhu optimal untuk perkecambahan konidium Beauveria bassiana adalah $25^{\circ} \mathrm{C}-30^{\circ} \mathrm{C}$, dengan suhu minimum $10^{\circ} \mathrm{C}$ dan maksimum $32^{\circ} \mathrm{C}$. Kemudian paparan waktu yang kurang lama juga dapat menyebabkan kematian imago Aedes aegypti kurang maksimal.

Menurut (Arsyiogi Hendra Samuel Sibarani, 2015) cara jamur Beauveria bassiana menginfeksi adalah dengan penetrasi ke dalam tubuh serangga melalui kulit luar di antara ruas-ruas. Mekanisme penetrasi dimulai dengan pertumbuhan konidia pada kutikula serangga dan mebentuk apresoria yang akhirnya membentuk hifa. Selanjutnya hifa cendawan tersebut mengeluarkan enzim kitinase, lipase, dan proteinase yang mampu menguraikan komponen menyusun kutikula serangga. Di samping itu cendawan ini juga memproduksi racun beauvericin yang dapat menyebabkan kerusakan pada jaringan maupun organ haemocoel serangga seperti saluran pencernaan, otot, sistem syaraf, dan system pernafasan. Akibat dari keseluruhan system di atas maka akan berakhir dengan kematian serangga.

\section{Data Hasil Uji Analisis Statistik}

Uji Analysis of Variance (ANOVA) bertujuan untuk menguji ke empat varians mempunyai rata-rata (mean) yang sama. Analisa yang dilakukan menggunakan uji ANOVA membutuhkan persyaratan uji normal. Pada data hasil uji tabel 4.4 dapat dilihat nilai sigifikannya Kolmogorov-Smirnov, untuk konsentrasi $10 \%<0.05$, konsentrasi $20 \%<0.05$, dan konsentrasi $30 \%<0.05$. Karena ke tiga konsentrasi nilai signifikannya kurang dari 0.05 maka dapat disimpulkan dari ke tiga konsentrasi tersebut tidak berdistribusi normal.

Syarat untuk melakukan uji ANOVA selanjutnya adalah Homogenity of variances atau data harus homogen. Test of Homogenety of Variances adalah analisis data yang bertujuan untuk menguji berlaku atau tidaknya asumsi untuk uji Analisis of Variances (ANOVA), yaitu ke empat varians mempunyai varians yang sama. Pada tabel 4.5 dapat dilihat nilai signifikansinya adalah 0.021 berarti $<0.05$ yang artinya data tidak homogen, maka tidak bisa dilanjutkan uji Analisis of Variances (ANOVA). Karena syarat dari uji ANOVA tidak terpenuhi yaitu data tidak berdistribusi normal dan tidak homogen maka data di uji dengan uji Krusskal Wallis dan dilanjutkan dengan uji U Mann Whitney untuk mengetahui konsentrasi yang paling efektif.

Hasil uji statistik Kruskal Wallis diperoleh nilai p (sig) $\leq 0,05$ yaitu $p=0,025$. Pada uji ini juga dapat disimpulkan bahwa konsentrasi yang paling banyak untuk mematikan imago Aedes aegypti yaitu konsentrasi $30 \%$ dengan rata-rata ranking 10, disusul konsentrasi $20 \%$ dengan rata-rata ranking 7 dan konsentrasi 10\% dengan rata-rata ranking 5. Kemudian karena hasil uji Krusskal Wallis signifikan, maka dilanjutkan dengan menggunakan uji U Mann Whitney untuk mengetahui perbedaan antara masing-masing konsentrasi terhadap kematian imago Aedes aegypti.

Hasil analisis uji $U$ Mann Whitney dapat disimpulkan bahwa hasil pengujian silang antara konsentrasi 10\%, konsentrassi 20\%, konsentrassi 30\% dan kontrol tidak semua Ha diterima. Hanya konsentrasi 10\% dengan konsentrasi 30\%, konsentrasi 20\% dengan kontrol dan konsentrasi 30\% dengan kontrol yang mempunya nilai Ha diterima yang artinya ada perbedaan antara masing - masing konsentrasi dengan kemtian imago Aedes aegypti.

Konsentrasi 30\% mempunyai daya bunuh yang paling tinggi dibanding konsentrasi 20\% dan 10\% karena konsentrasi $30 \%$ mempunyai zat terlarut bioinsektisida (Beauveria basssiana) paling banyak 
sehingga mempunyai tingkat pengenceran spora jamur atau kerapatan spora jamur Beauveria bassiana paling banyak dibandingkan dengan konsentrasi 20\% dan 10\%. Oleh karena itu konsentrasi 30\% lebih mampu membunuh imago Aedes aegypti lebih banyak. Hal ini dibuktikan dengan jumlah rata-rata kematian imago Aedes aegypti pada konsentrasi 30\% yaitu (18,6\%), konsentrasi 20\% yaitu (5,3\%) dan konsentrasi 10\% yaitu (1,3\%). Namun dari ketiga konsentrasi tersebut belum mencapai kematian > 90\% yang artinya belum dapat dikatakan efektif untuk membunuh imago Aedes aegypti.

Penelitian Maharani Herawan Ossa Putri, 2015 menunjukan hasil kematian imago Aedes aegypti pada pendedahan Beauveria bassiana selama 24 jam dengan konsentrasi $10^{-1}$ sampai $10^{-6}$ berturut - turut adalah $86 \%$, 70\%, 60\%, 50\%, 26\%, 10\% dan pendedahan selama 48 jam berturut - turut adalah 100\%, 90\%, 80\%, 63\%, 50\%, 33\%. Hal ini menujukkan bahwa jamur Beauveria bassiana pada tingkat konsentrasi spora yang semakin tinggi dan waktu infeksi semakin lama menyebabkan tingkat kematian yang semakin tinggi. Pada penelitian ini juga menunjukkan bahwa terjadi peningkatan kematian dari jam ke 24 sampai jam ke 48. Pada penelitian yang saya lakukan sudah terjadi peningkatan kematian dari jam ke 24 sampai jam ke 48, namun kematiannya $<90 \%$.

diantaranya:

Hal ini dapat disebabkan beberapa faktor

a. Waktu paparan yang digunakan kurang lama sehingga mempengaruhi jumlah kematian imago Aedes aegypti

b. Konsentrasi yang digunakan kurang pekat sehingga kerapatan spora jamur yang dihasilkan kurang tinggi

c. Kondisi lingkungan pada saat penyimpanan bioinsektisida (Beauveria basssiana) dimungkinkan tidak sesuai dengan suhu pertumbuhan jamur Beauveria bassiana tidak bisa tetap hidup sehingga bioinsektisida (Beauveria basssiana) yang digunakan tidak optimal. Menurut Goral dan Lappa dalam (Vina Nathalia, 2011) suhu optimal untuk perkecambahan konidium Beauveria bassiana adalah $25^{\circ} \mathrm{C}-30^{\circ} \mathrm{C}$, dengan suhu minimum $10^{\circ} \mathrm{C}$ dan maksimum $32^{\circ} \mathrm{C}$.

d. Penyimpanan bioinsektisida (Beauveria basssiana) yang terlalu lama dan pada saat penyimpanan di gudang bertumpuk - tumpuk yang dapat mengakibatkan kerusakan spora pada Beauveria bassiana

e. Penyimpanan yang tidak terjamin dapat mempengaruhi kualitas spora Beauveria bassiana yang dihasilkan

Adapun perbedaan - perbedaan metode yang dapat mempengaruhi perbedaan kematian imago Aedes aegypti yang saya gunakan dengan penelitian Maharani Herawan Ossa Putri, 2015. Diantaranya,
1. Pada penelitian Maharani Herawan Ossa Putri 2015, jamur di buat sendiri dengan media tepung jangung dan tepung beras, kemudian spora yang sudah jadi ditambahkan dengan larutan yang bersifat hidrofob kuat dan dapat tersuspensi dengan baik. Namun pada penelitian saya tidak ditambahkan dengan 40 tetes larutan Tween80 yang bersifat hidrofob dikarenkan sulit untuk menemukannya.

2. Penyimpanan bioinsektisida (Beauveria bassiana) yang sudah lama dibandingkan yang masih baru seperti yang di buat oleh Maharani Herawan Ossa Putri 2015, ketika spora Beauveria bassiana tumbuh langsung dapat digunakan untuk menginfeksi Imago Aedes aegypti. Hal tersebut dapat mempengaruhi perbedaan kematian Imago Aedes aegypti

3. Alat yang digunakan berbeda, pada Maharani Herawa Ossa Putri 2015, menggunakan tabung Milard sedangkan saya menggunakan botol spray biasa, sehingga kerapatan yang dihasilkan pada waktu penyemprotan berbeda.

Uji Regresi Linear sederhana digunakan untuk memperkirakan besarnya konsentrasi yang dapat membunuh $100 \%$ (25) imago Aedes aegypti. Pada uji ini dikonsentrasi yang dapat membunuh 25 imago Aedes aegypti adalah konsentrasi $125 \%$. Artinya presentase kematian imago Aedes aegypti sebanyak 100\% apabila menggunakan konsentrasi sebanyak 125\%. Dapat disimpulkan bahwa bioinsektisida Beauveria bassiana tidak efektif digunakan untuk pengendalian vektor imago Aedes aegyprti.

\section{Kesimpulan}

Dari hasil penelitian diatas dapat disimpulkan:

1. Jumlah kematian dari Imago Aedes aegypti pada konsentrasi $10 \%$ adalah 1,3\% (1), konsentrasi $20 \%$ adalah 5,3\% (4) dan konsentrasi 30\% adalah 18,6\% (14). Sehingga jumlah kematian tertinggi yaitu pada konsentrasi 30\% dan jumlah kematian terendah pada konsentrasi $10 \%$.

2. Hasil analisis uji statistik Krusskal Wallis adalah $\mathrm{p}=0,025$ yang artinya ada pengaruh berbagai konsentrasi bioinsektisida (Beauveria bassiana) terhadap kematian imago Aedes aegypti.

3. Hasil analisis perbedaan dengan uji U Man Whitney yaitu, konsentrasi $10 \%$ dengan kontrol yaitu tidak ada perbedaan, konsentrasi $20 \%$ dengan kontrol yaitu ada perbedaan, konsentrasi 30\% dengan kontrol yaitu ada perbedaan, konsentrasi 10\% dengan 20\% yaitu tidak ada perbedaan, konsentrasi $10 \%$ dengan $30 \%$ yaitu ada perbedaan dan konsentrasi $20 \%$ dengan $30 \%$ yaitu tidak ada perbedaan.

4. Bioinsektisida dengan bahan aktif Beauveria bassiana tidak efektif digunakan untuk membunuh imago Aedes aegypti karena kematian yang dihasilkan tidak mencapai > 90\%. 


\section{Ucapan Terima Kasih}

Terimakasih disampaikan kepada Balai Litbang P2B2 Banjarnegara yang telah menyediakan tempat sebagai tempat penelitian. Dosen pembimbing Karya Tulis Ilmiah serta pihak-pihak yang terkait sehingga penelitian ini dapat terlaksanakan tepat waktu.

\section{Daftar Pustaka}

Andy Kurniawan. 2012. Pengaruh Ekstrak Daun Suren (Toona Sureni) terhadap Kematian Nyamuk Aedes aegypti, Skripsi. Surakarta: Universitas Muhammadiyah Surakarta

Arsyiogi Hendra Samuel Sibarani. 2015. Patogenisitas Beauveria bassiana pada Spodoptera litura Fabricius. (Lepidoptera : Noctuidae) pada Tanaman Kelapa Sawit, Skripsi, Medan: Universitas Sumatera Fakultas Pertanian Utara Program Studi Agroekoteknologi.

Departemen Kesehatan RI, 2004, Pedoman Ekologi dan Aspek Perilaku Vektor, Jakarta : Ditjend : PPM \& PL

Departemen Kesehatan RI, 2007, Pedoman Ekologi dan Aspek Perilaku Vektor, Jakarta : Ditjend : PP \& PL

Depkes RI. 2012. Pedoman Pengendalian Demam Chikungunnya Edisi 2. Jakarta: Dirjen PP\& PL.

Farida Larasati. 2013. Efektifitas Ekstrak Daun Sirih (Piper Betle Linn) Sebagai Larvasida Alami Untuk Mematikan Larva Aedes aegypti Tahun 2013, Karya Tulis Ilmiah. Purwokerto: Kementrian Kesehatan RI Politeknik Kesehatan Semarang Jurusan Kesehatan Lingkungan Purwokerto

Memory Fitri Sitorus. 2013. Pemanfaatan Daun Tanaman Sukun (Artocarpus altilis) Sebagai Anti Nyamuk Mat Elektrik Dalam Membunuh Nyamuk Aedes, spp, Skripsi, Medan Universitas Sumatera Utara Fakultas Kesehatan Masyarakat

Peraturan Menteri Kesehatan Republik Indonesia Nomor : 374/ Menkes/PER/III/2010 Tentang Pengendalian Vektor.

Putri, Maharani Herawan Ossa, Hikmat Kasmara, Melanie. (2015). Jamur entomopatogen Beauveria bassiana (Balsamo, 1912) sebagai agen pengendali nyamuk Aedes aegypti (Linnaneus, 1762). Pros Sem Nas Masy Biodiv Indon. Volume 1, Nomor 6, Halaman 1472-1477.

Suris Trijayanti. 2015. Pengaruh Pemakaian Perasan Daun Selasih (Ocimum basilicum) Sebagai Repellent Terhadap Jumlah Hinggap Nyamuk Aedes aegypti Tahun 2015, Karya Tulis Ilmiah. Purwokerto: Kementrian Kesehatan RI Politeknik Kesehatan Semarang Jurusan Kesehatan Lingkungan Purwokerto

Vina Nathalia. 2011. Uji Patogenisitas Jamur Beauveria bassiana Vuill. Bals. Terhadap Kutu Gajah, Orchidophilus atterimus Wat., (Curculionidae,
Coleoptera), Skripsi, Yogyakarta: Universitas Atma Jaya Yogyakarta Fakultas Teknobiologi Program Studi Biologi. 